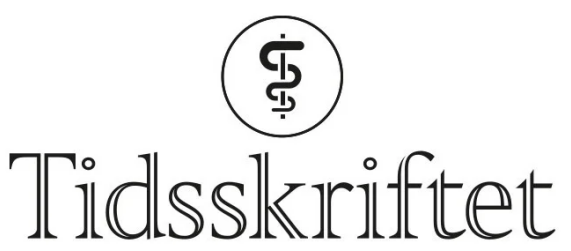

DEN NORSKE LEGEFORENING

\title{
Kreft i Norge
}

DEBATT

\section{GISKE URSIN}

giske.ursin@kreftregisteret.no

Giske Ursin er cand.med., ph.d. og direktør i Kreftregisteret. Hun sitter i redaksjonskomiteen for Cancer in Norway.

Forfatteren har fylt ut ICMJE-skjemaet og oppgir ingen interessekonflikter.

\section{TOM KRISTIAN GRIMSRUD}

Tom Kristian Grimsrud er dr.med., overlege og forsker ved Forskningsavdelingen, Kreftregisteret. Han sitter i redaksjonskomiteen for Cancer in Norway.

Forfatteren har fylt ut ICMJE-skjemaet og oppgir ingen interessekonflikter.

\section{JOHANNE GULBRANDSEN}

Johanne Gulbrandsen er MSHI og seksjonsleder ved Registeravdelingen, Kreftregisteret. Hun sitter i redaksjonskomiteen for Cancer in Norway.

Forfatteren har fylt ut ICMJE-skjemaet og oppgir ingen interessekonflikter.

\section{ELISABETH JAKOBSEN}

Elisabeth Jakobsen er MSc og kommunikasjonsleder ved Administrasjonsavdelingen, Kreftregisteret. Hun sitter i redaksjonskomiteen for Cancer in Norway. Forfatteren har fylt ut ICMJE-skjemaet og oppgir ingen interessekonflikter.

\section{TOM BØRGE JOHANNESEN}

Tom Børge Johannesen er dr.med., overlege og avdelingsnestleder ved Registeravdelingen, Kreftregisteret. Han sitter i redaksjonskomiteen for Cancer in Norway. Forfatteren har fylt ut ICMJE-skjemaet og oppgir ingen interessekonflikter.

\section{SIRI LARØNNINGEN}

Siri Larønningen er cand.scient. og spesialrådgiver ved Registeravdelingen, Kreftregisteret. Hun sitter i redaksjonskomiteen for Cancer in Norway.

Forfatteren har fylt ut ICMJE-skjemaet og oppgir ingen interessekonflikter.

\section{TRUDE EID ROBSAHM}

Trude Eid Robsahm er ph.d., forsker og seksjonsleder ved Forskningsavdelingen, Kreftregisteret. Hun sitter i redaksjonskomiteen for Cancer in Norway.

Forfatteren har fylt ut ICMJE-skjemaet og oppgir ingen interessekonflikter. 
Ann Helen Seglem er MHA og seksjonsleder ved Registeravdelingen, Kreftregisteret. Hun sitter i redaksjonskomiteen for Cancer in Norway.

Forfatteren har fylt ut ICMJE-skjemaet og oppgir ingen interessekonflikter.

\section{BJ $\varnothing R N$ M $\varnothing L L E R$}

Bjørn Møller er ph.d., forsker og avdelingsleder ved Registeravdelingen, Kreftregisteret. Han sitter i redaksjonskomiteen for Cancer in Norway.

Forfatteren har fylt ut ICMJE-skjemaet og oppgir ingen interessekonflikter.

\section{INGER KRISTIN LARSEN}

Inger Kristin Larsen er ph.d., forsker, seksjonsnestleder ved Registeravdelingen, Kreftregisteret og redaktør i Cancer in Norway.

Forfatteren har fylt ut ICMJE-skjemaet og oppgir ingen interessekonflikter.

\section{Kreftregisteret har nylig publisert krefttallene for 2019. Her er noen hovedpunkter.}

Totalt var det nær 35 ooo nye krefttilfeller i Norge i 2019 (11). Kort oppsummert flater noen kreftformer ut eller avtar i antall tilfeller, som prostatakreft og tarmkreft, mens andre fortsatt øker, som brystkreft og hudkreft av ikke-melanomtype.

\section{Nedgang for flere krefttyper}

Av de store kreftformene er det særlig raten for prostatakreft som har flatet ut og avtatt de siste årene. Dette kan reflektere en reell nedgang i testing for prostataspesifikt antigen (PSA) hos friske menn, eller at «screeningprevalenstoppen» er fjernet på grunn av intensiv PSA-testing over flere år.

Ratene for tarmkreft har også stabilisert seg og synes å avta for begge kjønn. Det gjelder særlig endetarmskreft.

Lungekreftraten for menn fortsetter heldigvis å gå ned, men er fremdeles den nest vanligste kreftformen hos menn. For kvinner er det dessverre ingen klar nedgang, og vi er ikke sikre på om toppen er nådd. I aldersgruppene under 6o år er lungekreft nå vanligere hos kvinner enn hos menn, og forekomsten øker raskt hos kvinner over 70 år.

Røyketallene har falt, men fremdeles røyker 12-15\% av kvinner og menn over 45 år, og det er

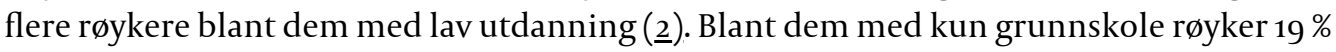
av menn og $24 \%$ av kvinner daglig. Røyking er, og forblir, den viktigste risikofaktoren for kreft, i tillegg til alder. Røykestopp reduserer risikoen, også om man slutter sent i livet.

\section{$\emptyset \mathrm{kning}$ for enkelte krefttyper}

Hos kvinner fortsetter antallet brystkrefttilfeller å øke. Fra forrige til nåværende femårsperiode er økningen særlig uttalt for kvinner i 70-årene. En del av årsaken er sannsynligvis at kvinner går til screening privat etter at de har mottatt siste invitasjon til Mammografiprogrammet. Hos kvinner i 6o- og 7o-årene kan nok tomosyntese også forklare noe av økningen. Tomosyntese er en sensitiv avbildningsmetode som kan påvise små svulster, særlig hos eldre kvinner der brystvev er erstattet med fettvev. Endringer i livsstilsfaktorer, som økt overvekt og alkoholkonsum over en lengre tidsperiode, kan også ha spilt inn. 
«Noen kreftformer flater ut eller avtar $i$ antall tilfeller, som prostatakreft

og tarmkreft, mens andre fortsatt øker, som brystkreft og hudkreft av

ikke-melanomtype»

Postmenopausal hormonbehandling har gitt insidensøkning over tid, men spiller nok begrenset rolle nå. Tall fra Reseptregisteret antyder at bruk av hormonell substitusjonsbehandling ved menopause, og særlig kombinasjonsbehandling med østrogen og gestagen (Go3F), har vært stabil og begrenset de siste ti årene (3).

Tallene for hudkreft av ikke-melanomtype øker fortsatt, for begge kjønn. Melanomratene ser derimot ut til å ha flatet ut de siste par årene. Å redusere skadelig soleksponering og bruk av solarium er fortsatt en viktig prioritet.

\section{Forsinket registrering}

Det er en viss forsinkelse i rapporteringen til Kreftregisteret. Normalt tilkommer rundt 500 krefttilfeller året etter at krefttallene er publisert. I tillegg mangler det i år informasjon om rundt 250 tilfeller vi normalt får med oss ved publisering. Årsaken er at Dødsårsaksregisteret naturlig nok i 2020 har måttet prioritere registrering av dødsfall knyttet til covid-19-pandemien. Dette påvirker i særlig grad tallene for lunge-, bukspyttkjertel-, tykktarm- og prostatakreft.

\section{Overlevelse}

For å beregne overlevelse sammenligner vi hvor mange kreftpasienter som er i live, med tilsvarende tall for befolkningen i samme aldersgruppe. Dette betegnes som relativ overlevelse. Vi forklarer ofte relativ overlevelse med «i hvilken grad man overlever kreftsykdommen», fordi vi ved sammenligningen justerer for andre dødsårsaker.

Den mest markante bedringen i fem års relativ overlevelse er for melanom i stadium IV, for begge kjønn. Overlevelsen ligger nå på nesten $50 \%$ hos kvinner og $34 \%$ hos menn. Dette er sannsynligvis en effekt av immunterapi. Ipilimumab ble besluttet innført for behandling av lokalavansert og metastatisk melanom i oktober 2014 (4), og i de påfølgende årene er flere legemidler og kombinasjonsbehandlinger blitt tilgjengelige.

For lungekreft har bedringen vært gradvis over flere tiår. Mye av forbedringen tilskrives at flere tilfeller oppdages i et tidlig stadium og blir operert eller gitt stereotaktisk strålebehandling (5-6). Den femårige relative overlevelsen for lokal sykdom er nå > 70 \% for kvinner og $>60 \%$ for menn. For regional sykdom er overlevelsen rundt $30 \%$ for begge kjønn.

Også for avansert brystkreft er det en gradvis forbedring i overlevelsen. Bedre behandling kan forklare noe. I tillegg utredes flere kvinner med positronemisjonstomografi (PET) og magnettomografi (MR), slik at metastaser oppdages. Dette kan også forklare hvorfor stadium IV-raten ikke har falt, selv om det var en forventet effekt av Mammografiprogrammet.

Det er også gradvise forbedringer for en rekke andre kreftformer med spredning. For noen kreftformer, som lever-, galleblære- og bukspyttkjertelkreft, er imidlertid prognosen fremdeles dårlig, med en fem års relativ overlevelse på 2-6\% i stadium IV. Dette er kreftformer som forekommer sjeldnere, men gjelder likevel nesten 500 nye pasienter i året: 100 med lever- og galleblærekreft og nesten 400 med bukspyttkjertelkreft i stadium IV. Vi håper at mer detaljert informasjon i det nye kvalitetsregisteret for bukspyttkjertelkreft vil gi ny kunnskap som kan bidra til å øke overlevelsen for disse pasientene. 


\section{LITTERATUR}

1. Cancer in Norway 2019 - Cancer incidence, mortality, survival and prevalence in Norway. Oslo: Kreftregisteret, 2020. https://www.kreftregisteret.no/globalassets/cancer-in-norway/2018/cin2018.pdf Lest 22.10.2020.

2. Statistisk Sentralbyrå. Statistikkbanken. Røyk, alkohol og andre rusmidler. Tabell o7662, 05307 og 11426. https://www.ssb.no/statbank/list/royk/ Lest 22.10.2020.

3. Reseptregisteret. Statistikk fra Reseptregisteret. http://www.reseptregisteret.no/Prevalens.aspx Lest 22.10.2020

4. Nye Metoder. Ipilimumab(Yervoy).https://nyemetoder.no/metoder/ipilimumab-yervoy Lest 22.10.2020.

5. Brustugun OT, Grønberg BH, Fjellbirkeland L et al. Substantial nation-wide improvement in lung cancer relative survival in Norway from 2000 to 2016. Lung Cancer 2018; 122: 138-45. [PubMed] [CrossRef]

6. Solberg S, Nilssen Y, Brustugun OT et al. Increase in curative treatment and survival of lung cancer in Norway 2001-2016. Eur J Epidemiol 2019;34: 951-5. [PubMed][CrossRef]

Publisert: 19. november 2020. Tidsskr Nor Legeforen. DOI: 10.4045/tidsskr.20.0853

Mottatt 23.10.2020, godkjent 3.11.2020.

(C) Tidsskrift for Den norske legeforening 2023. Lastet ned fra tidsskriftet.no 26. april 2023. 